\title{
ЕКОНОМІКА
}

$\begin{gathered}\text { Hayковий вісник НЛтУ України } \\ \text { Scientific Bulletin of UNFU } \\ \text { https://nv.nltu.edu.ua }\end{gathered}$
$\begin{aligned} & \text { https://doi.org/10.36930/40310512 } \\ & \text { Article received 08.11.2021 p. } \\ & \text { Article accepted 25.11.2021 p. } \\ & \text { UDC 338.2:349.6 }\end{aligned}$

${ }^{1}$ Львівський державний університет внутрішніх справ, м. Львів, Украӥна

${ }^{2}$ Національний лісотехнічний університет Украӥни, м. Львів, Украӥна

\section{ЗАБЕЗПЕЧЕННЯ ЕКОЛОГО-ЕКОНОМІЧНОЇ БЕЗПЕКИ У ПОСТКРИЗОВИЙ ПЕРІОД}

Збалансування екологічної та економічної систем є екстреною потребою сьогодення, яка виникла внаслідок активного економічного розвитку та нехтування екологічними обмеженнями. Результатом такої непродуманої активності стало вичерпання природних ресурсів, збільшення рівня забруднення довкілля та посилення глобальних екологічних проблем. Здійснений у цьому дослідженні теоретичний аналіз дає підстави стверджувати, що екологізація як безпекова діяльність, на сьогодні набула дуже вагомого значення в межах еколого-економічних систем, особливо у посткризовий період, коли всі країни намагатимуться якнайшвидше відновити економіку після завершення пандемії коронавірусу COVID-19. Проаналізовано можливі сценарії розвитку економіки після завершення пандемії та їх вплив на довкілля. Ідентифіковано найоптимальніший шлях, що полягає в економічному відновленні, яке супроводжуватиметься інтенсивними процесами екологізації економіки. Обгрунтовано, що такий шлях дасть змогу отримати найбільший еколого-економічний ефект та сприятиме подоланню глобальних екологічних проблем. Запропоновано вдосконалити систему управління екологізацією шляхом використання найефективніших інструментів екологізації та адаптувати іï до посткризових реалій. Для цього розроблено методику та алгоритм оцінки ефективності інструментів екологізації з використанням методу експертного опитування та методики Кендалла для оцінки узгодженості думок експертів. Встановлено ефективність інструментів екологізації та виокремлено найефективніші з них. Грунтуючись на результатах дослідження, розроблено основні заходи 3 удосконалення системи управління екологізацією економіки у посткризовий період шляхом інтенсифікації використання найефективніших інструментів. Оскільки у дослідженні з'ясовано, що екологічні податки є найефективнішим інструментом екологізації, оцінено їхню частку у структурі податкових платежів України та інших розвинених країн. На підставі цього підтверджено гіпотезу щодо необгрунтовано низьких ставок екологічних податків в Україні. Запропоновано низку управлінських заходів 3 екологізації економіки у посткризовий період.

Ключові слова: екологічна безпека; довкілля; економіко-правові заходи; методика Кендалла; інструменти екологізації; відновлювана енергія.

\section{Вступ / Introduction}

Сучасна економіка відзначається інтенсивним використанням ресурсів та істотним скороченням їх запасів, що спричиняє низку глобальних екологічних проблем i криз. Однак на сучасному етапі людство не може відмовитися від надаваних економікою благ та призупинити економічний розвиток, що зумовлено законом зростання потреб та збільшенням чисельності населення планети. Тому потребу забезпечення екологічно безпечного економічного розвитку $\epsilon$ домінантою сьогодення. Найоптимальнішим шляхом дослідники вважають шлях екологізації економіки. Варто зауважити, що внесла свої корективи у суспільно-економічне буття і пандемія коронавірусу COVID-19. Певною мірою вона сприяла покращенню екологічної ситуації, проте сприяла також деяким негативним процесам, що втілились у коронакризу. Відповідно, важливо встановити екологічно безпечні шляхи відновлення економіки у посткризовий період. 3 огляду на це розроблення ефективних заходів управління екологізацією сприятиме протидії глобальним екологічним проблемам та забезпечуватиме досягнення основних цілей економічного розвитку. Враховуючи зазначені аргументи, можна стверджувати про актуалізацію зазначеної проблематики управління екологізацією економіки у постпандемічний період.

Об'єкт дослідження - процеси екологізації економіки у посткризовий період.

\section{Інформація про авторів:}

Гобела Володимир Володимирович, канд. екон. наук, доцент, кафедра менеджменту. Email: mandos11@ukr.net; https://orsid.org/0000-0001-7438-2329

Дудюк Володимир Степанович, канд. екон. наук, доцент, кафедра менеджменту організацій і адміністрування. Email: v_dudjuk@nltu.edu.ua; https://orsid.org/0000-0003-4649-4280

Гобела Володимир Миколайович, асистент, кафедра лісопромислового виробництва та лісових доріг. Email: v.gobela@nltu.edu.ua; https://orsid.org/0000-0003-4649-4280

Цитування за Дсту: Гобела В. В., Дудюк В. С., Гобела В. М. Забезпечення еколого-економічної безпеки у посткризовий період. Науковий вісник НЛТУ України. 2021, т. 31, № 5. С. 79-83.

Citation APA: Hobela, V. V., Dudiuk, V. S., \& Hobela, V. M. (2021). Ensuring the environmental and economic security in the post-crisis period. Scientific Bulletin of UNFU, 31(5), 79-83. https://doi.org/10.36930/40310512 
Предмет дослідження - методи і засоби забезпечення еколого-економічної безпеки, що дасть змогу розробити заходи з удосконалення системи управління екологізацією у посткризовий період, які грунтуються на визначенні ефективності інструментів екологізації.

Мета дослідження - удосконалення заходів управління екологізацією на підставі використання ефективних інструментів та 3 урахуванням посткризових особливостей економічного розвитку.

Для досягнення зазначеної мети визначено такі основні завдання дослідження:

- оцінити ефективність інструментів екологізації за допомогою запропонованої методики;

- розробити заходи з управління екологізацією, що грунтуються на результатах здійсненого дослідження.

Наукова новизна отриманих результатів дослідження - вперше запропоновано заходи з удосконалення системи управління екологізацією у посткризовий період, що грунтуються на визначенні ефективності інструментів екологізації.

Практична значущість результатів дослідження результати дослідження дають змогу покращити систему управління екологізацією економіки 3 урахуванням особливостей посткризового періоду.

Аналіз останніх досліджень та публікацій. Характерною рисою сучасної економіки є низка глобальних екологічних проблем. Тому актуалізуються наукові дослідження проблем екологізації економіки та формування екологічно безпечної моделі економічного розвитку - "зеленої" економіки. Відповідно, представники наукового співтовариства активно досліджували проблеми формування зеленої економіки [1], побудови екологічно безпечної моделі економічного розвитку [6], а також проблеми екологічної економіки. Дослідженню загальних проблемам сталого розвитку та формування зеленої економіки присвячені праці м. Демітрова та К. Халфакpi [9]. Окреслену проблематику досліджували також українські науковці О. Чмир та Н. Захаркевич [5], зокрема вивчали проблеми забезпечення сталого розвитку та формування зеленої економіки. Актуальним напрямом дослідження вчених К. Шульца та Дж. Аффолдербаха став пошук шляхів реалізації принципів зеленої економіки як інструменту сталого навчання [19] та вивчення ролі сталого навчання у процесі забезпечення екологізації економіки, досліджуваного Гормалі А. [10]. П. Кумар і К. Тарнавська досліджували інновації та екоінновації як інструменти формування зеленої економіки [14, 22]. Не залишили поза увагою дослідники і проблеми екологізації міст та агломерацій [13].

Варто зауважити, що вчені активно досліджували взаємозв'язок між глобалізацією, споживанням енергії та економічним зростанням для сприяння розвитку зеленої економіки та навколишнього середовища. Їхні наукові розвідки дали змогу встановити зв'язок між зростанням ВВП і викидами вуглекислого газу та виявило двосторонній причинно-наслідковий зв'язок між економічним зростанням та використанням енергії [3]. Інші дослідники розглядали екологічне кредитування як інструмент зеленої економіки, що сприяє забезпеченню сталого розвитку [25]. С. Сауд, С. Чен, А. Хасіб та Сумайя здійснили аналіз впливу фінансового розвитку та глобалізації на довкілля та визначили показники для оцінки такого впливу [18]. Окрім цього, К. Тідбалл та А. Актіпіс встановили вплив прямих іноземних інвести- цій на зміну обсягів викидів $\mathrm{CO}_{2}$ у країнах, що розвиваються [23]. Учені Дж. Одугбесан, Х. Рхоуб та К. Іфедіора також вивчали наслідки економічного стимулювання забезпечення процесу формування зеленої економіки. Вони дійшли висновку, що економічне стимулювання є вкрай важливим аспектом для інтенсифікації процесів екологізації та формування зеленої економіки [16]. Переваги та недоліки, а також основні "вузькі" місця процесу формування зеленої економіки було визначено за допомогою багатовимірного підходу, запропонованого Деміралем м. та Деміралем О. [7]. Учені м. Наваз, У. Сешадрі та П. Кумар використали метод різниці у відмінностях (DID), щоб оцінити причинно-наслідкові ефекти оздоровлення довкілля внаслідок використання фінансових інструментів та пом'якшення наслідків зміни клімату в різних країнах [15].

Проте, незважаючи на велику кількість наукових досліджень, кілька питань залишилися недостатньо вивченими. Зокрема, особливості управління процесами екологізації після завершення пандемії та інтенсивного відновлення економіки та вибір оптимального інструментарію управління екологізацією. Відповідно, дослідження спрямоване на визначення еколого-економічних особливостей посткризового розвитку та встановлення ефективності інструментів екологізації, на підставі чого розроблено пропозиції щодо удосконалення системи управління екологізацією.

Матеріали та методи дослідження. У дослідженні використано декілька загальнонаукових методів дослідження, спрямованих на вивчення особливостей екологізації економіки та розроблення управлінських заходів для іiі інтенсифікації у посткризовий період. Зокрема, використано метод системного аналізу та синтезу для підтвердження гіпотези про ймовірне погіршення стану довкілля зумовленого швидкими темпами відновлення економіки після пандемії COVID-19. За допомогою методу аналітичного прогнозування та індукції визначено три ймовірні сценарії відновлення економіки та відповідний їм стан довкілля (та прогнозований стан довкілля відповідно до кожного сценарію). Використання методу експертного опитування дало змогу встановити найефективніші інструменти екологізації. Валідність результатів опитування підтверджена розрахунком показника узгодженості думок експертів за допомогою методики Кендалла. Використовуючи метод експертного опитування та порівняльно-аналітичний метод, виявлено причину неефективності екологічного оподаткування. За результатами дослідження розроблено низку управлінських заходів для екологізації економіки у посткризовий період, що грунтуються на використанні найефективніших інструментів екологізації.

\section{Результати дослідження та їх обговорення / Research results and their discussion}

Незважаючи на прогнозовані тяжкі наслідки пандемії COVID-19 для світової економіки, треба зауважити, що карантинні обмеження призвели до покращення стану довкілля. Однак поліпшення стану довкілля відбувається на фоні економічної кризи та загальної рецесії. Відповідно, зниження обсягів забруднення триватиме до поступового послаблення карантинних обмежень, що сприятиме зростанню економічної активності та призведе до протилежних наслідків - збільшення обсягів промислового виробництва та забруднення довкіл- 
ля. Саме тому зараз потрібно обрати шлях відновлення економіки у посткризовий період для отримання оптимального еколого-економічного ефекту. Важливо врахувати попередній невдалий досвід відновлення економіки після кризи у 2008-2009 рр., коли рівень забруднення довкілля у посткризовий період значно перевищував докризовий рівень [12]. Причиною цього стало значне збільшення темпів економічної активності та споживання вуглецю i, як наслідок, істотне збільшення забруднення довкілля та зростання викидів парникових газів.

Грунтуючись на результатах теоретичного аналізу та дослідженнях науковців [12, 18, 19] прогнозовані наслідки пандемії COVID-19 для економічної системи та довкілля є такими:

1. Економічна та екологічна криза. Після закінчення пандемії люди зрозуміють, що вирішення кліматичних проблем і глобальних екологічних проблем - це занадто "дороге" задоволення, оскільки вимагає пожертвувати звичним і комфортним способом життя. Наслідком цього може стати екологічний волюнтаризм - повне ігнорування ідей екологічної економіки та остаточної індустріалізації, що пришвидшить екологічну катастрофу в глобальному масштабі.

2. Відновлення економіки та екологічна криза. Активне стимулювання промислового відновлення призведе до посилення антропогенного впливу на природу. За такого сценарію настання нових катаклізмів - питання часу.

3. Відновлення економіки та покращення стану довкілля Для цього необхідно сформувати систему управління економічним відновленням на принципах екологічно безпечного розвитку та екологізації.

Вважаємо, що найбільш прийнятним та оптимальним $з$ еколого-економічної точки зору є третій сценарій. Відповідно, виникає потребу розробити заходи з управління екологізацією для відновлення економіки екологічно безпечним способом. Для цього потрібно оцінити ефективність інструментів екологізації та сформувати управлінські заходи на підставі використання цих інструментів.

Для реалізації цього підходу використано такий алгоритм (рис. 1).

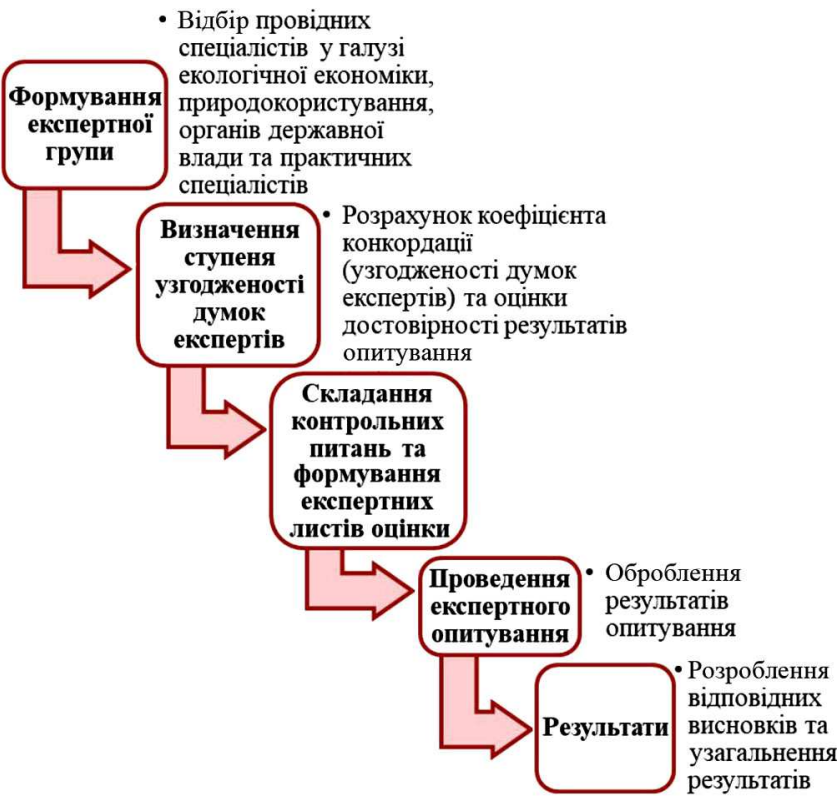

Рис. 1. Алгоритм експертного опитування для розрахунку ефективності інструментів екологізації / Algorithm of expert survey for calculating the effectiveness of greening tools
Для визначення узгодженості думок членів експертної групи використано методику Кендалла, яка передбачає розрахунок загального коефіцієнта рангової кореляції - коефіцієнта конкордації. Наближення цього показника до 1,0 означає більший ступінь згоди між експертами, і навпаки. Зазначимо, що граничне значення коефіцієнта конкордації 0,5 . Тобто значення показника більше 0,5 - думки узгоджені, менше 0,5 - думки не узгоджені. Коефіцієнт конкордації розраховуємо за такою формулою:

$$
W=\frac{12 \cdot S}{m^{2}\left(n^{3}-n\right)},
$$

де: $W$ - коефіцієнт конкордації; $S$ - сума квадратів відхилень; $m$ - кількість експертів; $n$ - кількість об'єктів (параметрів).

Відповідно, для оцінювання валідності думки експертів розрахували коефіцієнт конкордації за наведеною формулою. Оцінку виконано за чотирма параметрами, кількість експертів становила 10 осіб. Для обчислення коефіцієнта розрахували такі показники: $S$ - сумарний ранг об'єкта; $d$ - відхилення суми рангів від середньої суми рангів; $d^{2}-$ квадрат відхилення; $\Sigma d^{2}-$ сума квадратів відхилень (таблиця).

Таблиця. Вихідні дані для розрахунку коефіціснта конкордації / Initial data for calculating concordance coefficient

\begin{tabular}{|c|c|c|c|c|c|c|c|c|c|c|c|c|c|}
\hline Екеперт & 1 & 2 & 3 & 4 & 5 & 6 & 7 & 8 & 9 & 10 & $\mathrm{~S}$ & $d$ & $d^{2}$ \\
\hline Параметр 1 & 4 & 3 & 4 & 4 & 4 & 3 & 4 & 3 & 4 & 3 & 36 & -11 & 121 \\
\hline Параметр 2 & 2 & 4 & 2 & 3 & 3 & 4 & 3 & 4 & 3 & 2 & 30 & -5 & 25 \\
\hline Параметр 3 & 1 & 2 & 3 & 1 & 2 & 2 & 1 & 2 & 1 & 4 & 19 & 6 & 36 \\
\hline Параметр 4 & 3 & 1 & 1 & 2 & 1 & 1 & 2 & 1 & 2 & 1 & 15 & 10 & 100 \\
\hline$\Sigma d^{2}$ & \multicolumn{10}{|c|}{} \\
\hline
\end{tabular}

Підставляючи отримані результати у формулу (1), розрахували коефіцієнт конкордації, який дорівнює 0,564 . Отримане значення перевищує граничне значення коефіцієнта узгодженості і засвідчує обгрунтованість експертних висновків. За результатами дослідження встановлено найефективніші інструменти екологізації (рис. 2).

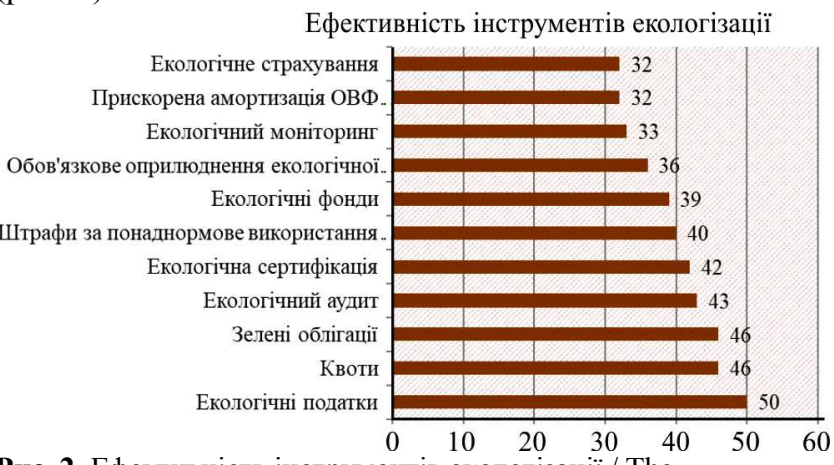

Рис. 2. Ефективність інструментів екологізації / The effectiveness of the greening tools

На підставі дослідження ефективності інструментів екологізації пропонуємо розробити заходи з активізації екологізації та переходу до зеленої економіки. Серед основних пропозицій розглянемо такі:

- підвищення екологічних податків;

- запровадження та використання зелених облігацій;

- створення Фонду охорони навколишнього природного середовища.

По-перше, результати дослідження показали, що екологічні податки мають істотний вплив на довкілля. Однак ці види податків не настільки ефективні. Вважаємо, що причиною цього є надто низька ставка по- 
датку (0,36 дол. за 1 т $\left.\mathrm{CO}_{2}\right)$ в Україні порівняно з іншими промислово розвиненими країнами (від 20 до 150 дол. США за 1 т $\mathrm{CO}_{2}$ ) [12].

Дослідження частки екологічних податків у структуpi податкових платежів України та інших розвинених країн підтверджує гіпотезу про необгрунтовано низькі ставки екологічного податку в Україні. Відповідно, виникає потреба у встановленні екологічного податку на рівні, який буде компенсувати екологічну шкоду та сприяти зниженню енергоємності виробництва. Зокрема, підвищення розміру екологічного податку в Україні від 0,02 до 0,36 доларів США спричинило зменшення обсягів викидів $\mathrm{CO}_{2}$. Дані аналізу показують, що 3 2017 р. скорочуються викиди $\mathrm{CO}_{2}$, що є наслідком підвищення екологічних податків в Україні.

По-друге, екологізація економіки та перехід на використання відновлюваної енергії є загальновизнаним стратегічним напрямом розвитку світової спільноти та України. Однак цей процес не настільки активний, як хотілося б. Проаналізуємо частку відновлюваної енергетики в Україні за 2015-2019 рр. (рис. 3). Як бачимо, показники в Україні надзвичайно низькі. Тому актуальним стало використання одного 3 найефективніших інструментів екологізації - зелених облігацій.

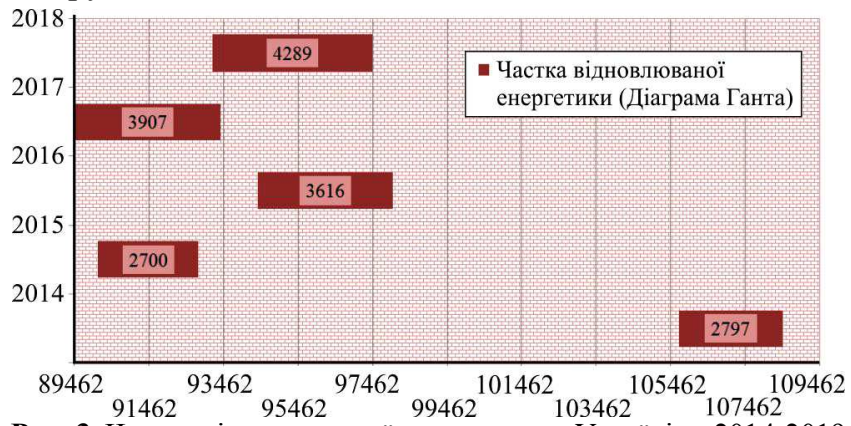

Рис. 3. Частка відновлюваної енергетики в Україні за 2014-2019

pp. / The share of renewable energy in Ukraine in 2014-2018 [8]

По-третє, проаналізувавши чинне законодавство та надходження до державного бюджету [11], робимо висновок, що здебільшого екологічні податки надходять до цього фонду не в повному обсязі. Також є багато прикладів нераціональності та нецільового використання коштів фонду. Найкращим рішенням цієї проблеми вважаємо створення Фонду охорони довкілля як окремої юридичної особи, яка буде акумулювати всі екологічні платежі.

Обговорення результатів дослідження. Результати дослідження підтверджують важливість екологізації економіки як засобу екологічно безпечного розвитку економіки в період після завершення пандемії COVID19. Актуальність досліджуваної проблематика зумовлена наявністю низки глобальних екологічних проблем. Попередні наукові розвідки спрямовувались на дослідження ефективності інструментів екополітики $[4,20]$, екологізації економіки і суспільного розвитку [21] та сучасні аспекти застосування інструментів екологізації [24]. Проте застосування інструментарію екологізації в період економічного відновлення після коронакризи $\epsilon$ мало дослідженою сферою наукових пошуків. Варто зазначити, що вчені досліджували особливості економічного розвитку у посткризовий період 2008-2009 pp. та відновлення постстихійних катаклізмів у деяких країнах [23] тощо. Відповідно, отримані результати дослі- дження дають змогу вдосконалити систему управління екологізацією у період після завершення пандемії.

\section{Висновки / Conclusions}

На підставі результатів теоретичного аналізу визначено прогнозовані сценарії стану довкілля залежно від способу відновлення економіки: економічна та екологічна кризи; відновлення економіки та екологічна криза; відновлення економіки та покращення екологічної ситуації.

У дослідженні запропоновано метод оцінювання ефективності інструментів екологізації для визначення найефективніших 3 них. Для цього було сформовано алгоритм, який складається 3 таких етапів: формування експертної групи; визначення ступеня узгодженості думок експертів шляхом розрахунку коефіцієнта узгодженості та оцінки достовірності результатів опитування; складання контрольних питань і формування експертних оцінкових листів; проведення експертного опитування та оброблення результатів опитування; вироблення відповідних висновків та узагальнення результатів.

Завдяки цьому методу визначено найефективніші інструменти екологізації економіки України у посткризовий період: екологічні податки, квоти, екологічні фонди, екологічний аудит, екологічна сертифікація. За результатами дослідження запропоновано шляхи удосконалення заходів з управління екологізацією у посткризовий період, що розроблені на підставі використання ефективних інструментів.

\section{References}

1. Affolderbach, J. (2020). Translating green economy concepts into practice: ideas pitches as learning tools for sustainability education. Journal of Geography in Higher Education. https://doi.org/10.1080/03098265.2020.1849063

2. Anser, K. M., Usman, M., Godil, D. I., Shabbir, M. S., Sharif, A., Tabash, M. I. \& Bares Lopez, L. (2021). Correction to: Does globalization affect the green economy and environment? The relationship between energy consumption, carbon dioxide emissions, and economic growth. Environ Sci Pollut Res. http://doi.org/10.1007/s11356-021-14243-4

3. Ascensao, F., Fahrig, L., Clevenger, A., et. al. (2018). Environmental challenges for the Belt and Road Initiative. Nature Sustainability, 5, 206-209. https://doi.org/10.1038/s41893-018-0059-3

4. Bukanov, H. M. (2019). Stratehichni instrumenty realizatsii derzhavnoi ekolohichnoi polityky v Ukraini. Publichne upravlinnia: teoriia i praktyka, 2(22). Retrivied from: http://www.dridu.dp.ua/zbirnik/2019-02(22)/7.pdf. [In Ukrainian].

5. Chmyr, O., \& Zakharkevych, N. (2013). "Zelena" ekonomika: sutnist, tsili ta bazovi pryntsypy. Ekonomichnyi visnyk Donbasu, 33, 54-62. Recovered from: http://dspace.nbuv.gov.ua/handle/123456789/123331?show=full. $\quad$ [In Ukrainian].

6. Daly, H., \& Farley, J. (2004). Ecological Economics. Principles and applications. Washington: Island Press.

7. Demiral, M., \& Demiral, O. (2021). Where is the gray side of green growth? Theoretical insights, policy directions, and evidence from a multidimensional approach. Environ Sci Pollut Res. https://doi.org/10.1007/s11356-021-13127-x

8. Derzhavna sluzhba statystyky Ukrainy. (2016). Enerhospozhyvannia na pidstavi vidnovliuvanykh dzherel. Retrieved from: http://www.ukrstat.gov.ua/. [In Ukrainian].

9. Dymitrow, M., \& Halfacree, K. (2018). Sustainability - differently. Bulletin of Geography. Socioeconomic Series, 40(40), 7 16. https://doi.org/10.2478/bog-2018-0011

10. Gormally, A. (2019). The role of sustainability in HE and the GEES disciplines; recommendations for future practice. Journal of 
Geography in Higher Education, 43(4), 599-608. https://doi.org/10.1080/03098265.2019.1660627

11. Hobela, V. (2021). Ekonomiko-bezpekova ekolohizatsiia: teoriia $i$ praktyka. Lviv: LvDUVS. Retrieved from: http:/dspace.lvduvs.edu.ua/handle/1234567890/3757. [In Ukrainian].

12. Hobela, V., Blikhar, M., Syrovackyi, V., Maraieva, U., \& Dudiuk, V. (2021). Economic and legal measures for ensuring the economy greening in the post-pandemic period. Amazonia Investiga, 10(44), 252-260. https://doi.org/10.34069/AI/2021.44.08.24

13. Juhola, S. (2018). Planning for a green city: the Green Factor tool. Urban Forestry and Urban Greening, 34, 254-258. http://doi.org/10.1016/j.ufug.2018.07.019

14. Kumar, P. (2017). Innovative tools and new metrics for inclusive green economy. Current opinion in environmental sustainability, 24, 47-51. http://doi.org/10.1016/j.cosust.2017.01.012

15. Nawaz, M. A., Seshadri, U., Kumar, P., et. al. (2021). Nexus between green finance and climate change mitigation in N-11 and BRICS countries: empirical estimation through difference in differences (DID) approach. Environ Sci Pollut Res, 28, 6504-6519. https://doi.org/10.1007/s11356-020-10920-y

16. Odugbesan, J. A., Rjoub, H., Ifediora, C. U., et. al. (2021). Do financial regulations matters for sustainable green economy: evidence from Turkey. Environmental Science and Pollution Research. https://doi.org/10.1007/s11356-021-14645-4

17. Pearce, D. (1990). Blueprint 2: Greening the world economy. London: Earthscan Publications ltd.

18. Saud, S., Chen, S., Haseeb, A., \& Sumayya. (2020). The role of financial development and globalization in the environment: Accounting ecological footprint indicators for selected one-belt-oneroad initiative countries. Journal of Cleaner Production. http://doi.org/10.1016/j.jclepro.2019.119518
19. Schulz, C., \& Affolderbach, J. (2015). Grünes Wachstum und alternative Wirtschaftsformen (Green growth and alternative forms of economy). Geographische Rundschau (Geographical survey), 5, 4-9. Recovered from: https://www.westermann.de/anlage/4567354/GruenesWachstum-und-alternative-Wirtschaftsformen

20. Syniakevych, I. M. (2015). Ekolohichna polityka: stratehiia podolannia hlobalnykh ekolohichnykh zahroz: monohrafiia. Lviv: ZUKTs. [In Ukrainian].

21. Syniakevych, I. M., Holovko, A. A., Kovalyshyn, V., Polovskyi, A. M. (2015). Ekolohizatsiia suchasnoho suspilnoho zhyttia v konteksti podolannia ekolohichnykh zahroz i zmitsnennia ekolohichnoi bezpeky. Scientific Bulletin of UNFU, 25(13), 186 p. [In Ukrainian].

22. Tarnawska, K. (2013). Eco-innovations - tools for the transition to green economy. Economics and Management, 18, 735-743. http://doi.org/10.5755/j01.em.18.4.4485

23. Tidball, K. G., \& Aktipis, A. (2018). Feedback enhances greening during disaster recovery: A model of social and ecological processes in neighborhood scale investment. Urban Forestry \& Urban Greening, 34, 269-280. https://doi:10.1016/j.ufug.2018.07.005

24. Ushakova-Kyrpach, I. M. (2013). Suchasni aspekty realizatsii ekonomichnykh instrumentiv ekolohichnoi polityky Ukrainy. Visnyk sotsialno-ekonomichnykh doslidzhen, 2(57), 210-217. [In Ukrainian].

25. Xie, Q., Wang, X., \& Cong, X. (2020). How does foreign direct investment affect $\mathrm{CO}_{2}$ emissions in emerging countries? New findings from a nonlinear panel analysis. Clean Prod. Elsevier Ltd. http://doi.org/10.1016/j.jclepro.2019.119422

26. Yuan, F., \& Gallagher, K. P. (2018). Greening development lending in the Americas: trends and determinants. Ecological Economics. Elsevier, 154, 189-200. http://doi.org/10.1016/j.ecolecon.2018.07.009

V. V. Hobela1, V. S. Dudiuk', V. M. Hobela ${ }^{2}$

${ }^{1}$ Lviv State University of Internal Affairs, Lviv, Ukraine

${ }^{2}$ Ukrainian National Forestry University, Lviv, Ukraine

\section{ENSURING THE ENVIRONMENTAL AND ECONOMIC SECURITY IN THE POST-CRISIS PERIOD}

Ensuring environmental and economic security is an important task of the modern generation, as a number of global environmental problems require both measures to address them, and also to restructure the overall concept of social development. The study aimed to develop effective measures to ensure environmental and economic security in the post-crisis period - the period after the end of the pandemic. Therefore, the study used several general scientific research methods aimed at investigating the peculiarities of the greening of the economy and the development of management measures for its intensification. That is to say, the paper presents the methods of system analysis, synthesis, comparative-analytical, analytical forecasting, induction, expert survey, Kendall's method, and the method of theoretical generalization. The study identified the most optimal scenario for economic recovering based on the theoretical analysis of the forecasted scenarios of economic development in the post-crisis period and the corresponding state of the environment. The research established the need to intensive the economy greening to prevent several threats that may occur as a result of economic recovery after the end of the coronavirus pandemic COVID-19. Moreover, the research proposed an algorithm for evaluating the effectiveness of greening tools using the method of an expert survey. The expert groups and questionnaires for the survey were formed. Furthermore, the concordance coefficient was calculated to determine the agreement of experts' opinions and confirm the validity of the survey results. Having analyzed the results of the research, the study established the efficiency of the economy greening tools and the most effective of them. The peculiarities of the use of the most effective greening tools are analysed; several shortcomings concerning their use are revealed. As a result, the corresponding recommendations were made. Consequently, the research has developed some management measures for the economy greening in the post-crisis period based on the use of the most effective greening tools.

Keywords: ecological security; environmental; economic and legal measures; Kendall methodology; greening tools; renewable energy. 